\title{
Construction and Extraction Occupations
}

National Cancer Institute

\section{Source}

National Cancer Institute. Construction and Extraction Occupations. NCI Thesaurus.

Code C97630.

A class of professional or vocational positions of employment that involve construction or extraction. 